\title{
Analysis of Serum Uric Acid Level in Patients with and without Diabetic Nephropathy
}

\author{
Erika Rosaria Simbolon ${ }^{1}$, Suci Aprianti ${ }^{1,2}$, Nurahmi ${ }^{1,3}$, Liong Boy Kuniawan ${ }^{1}$ \\ ${ }^{1}$ Department of Clinical Pathology, Faculty of Medicine of Hasanuddin University/Dr. Wahidin Sudirohusodo Hospital, Makassar, Indonesia. \\ E-mail: erikarosariasimbolon@gmail.com \\ ${ }^{2}$ Haji Hospital, Makassar, Indonesia \\ ${ }^{3}$ Kota Makassar Hospital, Makassar, Indonesia
}

\begin{abstract}
Diabetic nephropathy is one of the microvascular complications in type 2 Diabetes Mellitus (DM). Diagnosis of diabetic nephropathy is based on any history of DM, a decrease in Glomerular Estimation Filtrate Rate (eGFR) using the CKD-Epi formula, and albuminuria. The role of serum uric acid level in diabetic nephropathy remains an ongoing debate. Serum uric acid levels may be the cause or the result of diabetic nephropathy. This study aimed to analyze serum uric acid levels in patients with and without diabetic nephropathy and determine its correlation with diabetic nephropathy. This study was performed at Dr. Wahidin Sudirohusodo Hospital, Makassar, by taking the data from the medical record of type 2 DM patients from January to April 2018. Fifty-nine patients with diabetic nephropathy and 150 patients without diabetic nephropathy participated in this study. An independent T-test and Pearson's correlation test were used for statistical analysis. There was a significant difference in uric acid level between patients with and without diabetic nephropathy $(9.57 \pm 3.42 \mathrm{mg} / \mathrm{dL}$ vs. $6.41 \pm 2.86 \mathrm{mg} / \mathrm{dL}, \mathrm{p}<0.001)$. There was significant correlation between uric acid serum levels with urea $(p<0.001, r=0.585)$, creatinine $(p<0.001, r=0.413)$ and eGFR $(p<0.001, r=-0.525)$ in patients with diabetic nephropathy. Uric acid levels in patients with diabetic nephropathy were higher than patients without diabetic nephropathy. Higher levels of urea and the serum creatinine led to higher levels of serum uric acid. Contrastingly, a lower eGFR rate led to higher levels of uric acid.
\end{abstract}

Keywords: Diabetic nephropathy, uric acid, urea, creatinine, eGFR

\section{INTRODUCTION}

Uric acid is the end product of purine metabolism, which is catalyzed by the xanthine oxidase. Uric acid is mainly produced in the liver and is mostly excreted through the kidneys. Increased serum uric acid levels are associated with increased hypertension, insulin resistance, cardiovascular disease, and chronic renal failure. ${ }^{1,2}$

Type 2 DM is a group of metabolic diseases characterized by hyperglycemia, which occurs due to abnormalities in insulin secretion, insulin action, or both. According to the Indonesian Association of Endocrinology (Perkeni) in 2015, the criteria for the diagnosis of type 2 diabetes are fasting plasma glucose $\geq 126 \mathrm{mg} / \mathrm{dL}$ or plasma glucose $\geq 200$ $\mathrm{mg} / \mathrm{dL}$ after an oral glucose tolerance test (TTGO) or random plasma glucose $\geq 200 \mathrm{mg} / \mathrm{dL}$ with classic complaints or $\mathrm{HbAlc}$ values $\geq 6.5 \% .^{3.4}$ The report on the results of primary health research (Riskesdas) in 2018 by the Ministry of Health of the Republic of
Indonesia shows that the average prevalence of DM in people aged $\geq 15$ years is $10.9 \% .^{5}$

Diabetic nephropathy is one of the microvascular complications of type 2 diabetes. Diagnosis of diabetic nephropathy is made if albumin level $>30$ $\mathrm{mg}$ in the 24-hour urine at least 2 out of 3 examinations within 3-6 months was reported without other causes of albuminuria. The mechanism of diabetic nephropathy is unclear, but it is probably due to the dilatation of afferent arterioles by glucose-dependent effects mediated by the vasoactive hormones such as IGF-1, nitric oxide, prostaglandins, and glucagon., ${ }^{3,4}$ Diagnosis of diabetic nephropathy at Dr. Wahidin Sudirohusodo Hospital was established based on a history of DM, an eGFR with the CKD-Epi formula albuminuria using a urinalysis instrument with a random urine sample.

The role of uric acid in the incidence of diabetic nephropathy remains an ongoing debate. Jalal et al. suggested that the increased xanthine oxidation of uric acid will produce oxidative stress, contributing 
to endothelial dysfunction. ${ }^{6}$ Hyperuricemia caused blood vessel hypertension and kidney injuries such as damage to afferent arterioles, mesangial expansion, glomerular hypertrophy, and albuminuria.' Several studies have found that in addition to its role as a pro-oxidant, uric acid can have a protective function as an anti-oxidant. ${ }^{8-10}$ These anti-oxidant properties of uric acid enable the production of urate oxidant, which can uptake the free radicals. ${ }^{8,9}$

Based on this background, the authors were interested in researching the analysis of serum uric acid in type $2 \mathrm{DM}$ patients with and without diabetic nephropathy and serum uric acid's role in predicting the incidence of diabetic nephropathy.

\section{METHODS}

This research was a retrospective study with a cross-sectional method, which was carried out by taking secondary data of patients diagnosed with type 2 DM with and without diabetic nephropathy in Medical Records of Dr. Wahidin Sudirohusodo Hospital, Makassar for the period of January-April 2018.

This study's population was the medical records of patients diagnosed with type 2 DM with and without diabetic nephropathy at the Internal Medicine Clinic of Dr. Wahidin Sudirohusodo Hospital, Makassar. The research samples were all accessible populations with data of urea, creatinine, serum uric acid, and urinalysis at Dr. Wahidin Sudirohusodo Hospital, Makassar, for the period of January-April 2018. The inclusion criteria were all type 2 DM patients with diabetic nephropathy and without diabetic nephropathy, whose complete results of serum uric acid, urea, creatinine, and urinalysis in their medical records. Exclusion criteria were patients in the medical history receiving uric

\section{RESULTS AND DISCUSSIONS}

Table 1. Characteristics of research subjects $(n=209)$ acid-lowering medication and patients with malignant disease.

Measurement of urea, creatinine, and uric acid levels was carried out using a chemistry analyzer, such as Pentra 400, or Conelab or Indico. Estimated Glomerular Filtration Rate (eGFR) was calculated using the CKD-Epi formula as follows:

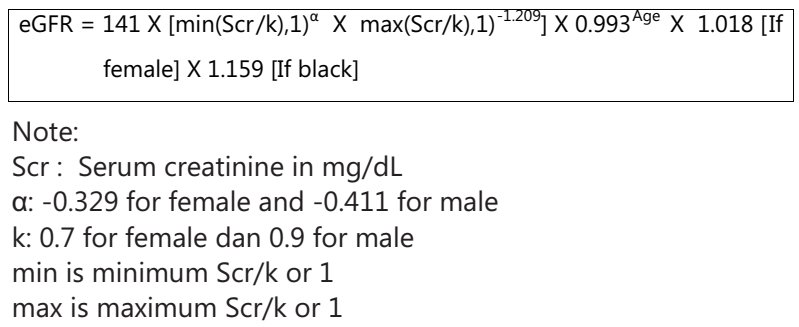

The eGFR values were divided into several categories. The eGFR value $\geq 90 \mathrm{~mL} / \mathrm{min} / 1.73 \mathrm{~m}^{2}$ were classified in the normal or high category, eGFR $60-89 \mathrm{~mL} / \mathrm{min} / 1.73 \mathrm{~m}^{2}$ was classified is in the mildly decreased category, eGFR $45-59 \mathrm{~mL} / \mathrm{min} / 1.73 \mathrm{~m}^{2}$ was classified in the mildly to a moderately decreased category, eGFR $30-44 \mathrm{~mL} / \mathrm{min} / 1.73 \mathrm{~m}^{2}$ was classified in the moderate to severely decreased category, eGFR $15-29 \mathrm{~mL} / \mathrm{min} / 1.73 \mathrm{~m}^{2}$ was classified in the severely decreased category and eGFR $<15 \mathrm{~mL} / \mathrm{min} / 1.73 \mathrm{~m}^{2}$ was classified as kidney failure. Data were analyzed using computer software.

Data were analyzed using the Kolmogorov-Smirnov normalization test. An independent T-test was used to compare serum uric acid levels in patients with diabetic nephropathy and without diabetic nephropathy. Pearson's correlation test was used to analyze the uric acid correlation with urea, creatinine, and eGFR. The results were significant, with $p \leq 0.05$.

The research permission was obtained from the Health Research Ethics Committee of the Hasanuddin University Medical Faculty/Dr. Wahidin Sudirohusoso Hospital with a number of 369/UN4.6.4.5.31/PP36/2019.

\begin{tabular}{lcccc}
\hline \multicolumn{1}{c}{ Variable } & $\mathbf{n ~ ( \% )}$ & Minimum & Maximum & Mean \pm SD \\
\hline Gender & & & & \\
Male & $110(52.6 \%)$ & & & \\
Female & $99(47.4 \%)$ & & & \\
Age (years) & & 25 & 85 & $58.77 \pm 10.32$ \\
Urea $(\mathrm{mg} / \mathrm{dL})$ & 5 & 321 & $70.38 \pm 66.88$ \\
Creatinine $(\mathrm{mg} / \mathrm{dL})$ & & 0.30 & 15.96 & $2.46 \pm 3.05$ \\
eGFR $\left(\mathrm{mL} / \mathrm{min} / 1.73 \mathrm{~m}^{2}\right)$ & & 2.70 & 143.70 & $60.92 \pm 37.49$ \\
Uric acid $(\mathrm{mg} / \mathrm{dL})$ & 2.20 & 17.70 & $7.30 \pm 3.34$ \\
\hline
\end{tabular}


Table 2. serum uric acid levels in type 2 DM patients without diabetic nephropathy

\begin{tabular}{cccc}
\hline Group & n (\%) & Mean \pm SD & p \\
\hline With diabetic nephropathy & $59(28.23)$ & $9.57 \pm 3.42$ & 0.001 \\
Without diabetic nephropathy & $150(71.77)$ & $6.41 \pm 2.86$ & \\
\hline
\end{tabular}

Independent T-test

Table 1 shows the characteristics of the study subjects. The total number of patients who participated in this study was 209 patients consisting of 110 (52.6\%) male patients and 99 (47.4\%) female patients. The mean age of the patients was $58.77 \pm 10.32$ years. The mean of urea, creatinine, eGFR, and uric acid were $70.38 \pm 66.88 \mathrm{mg} / \mathrm{dL}$, $2.46 \pm 3.05 \mathrm{mg} / \mathrm{dL}, 60.92 \mathrm{~mL} / \mathrm{min} / 1.73 \mathrm{~m}^{2}$, and $7.30 \pm 3.34 \mathrm{mg} / \mathrm{dL}$, respectively.

Table 2 shows that the mean serum uric acid levels in diabetic nephropathy patients were higher than those without diabetic nephropathy. The mean serum uric acid level in diabetic nephropathy patients was $9.57 \mathrm{mg} / \mathrm{dL}$ and in patients without diabetic nephropathy was $6.41 \mathrm{mg} / \mathrm{dL}$.

Table 3. Correlation between serum uric acid, urea, creatinine, and eGFR

\begin{tabular}{lccc}
\hline \multicolumn{1}{c}{ Variable } & $\mathbf{n}$ & $\mathbf{p}$ & $\mathbf{r}$ \\
\hline Urea & 209 & 0.001 & 0.585 \\
Creatinine & 209 & 0.001 & 0.413 \\
eGFR & 209 & 0.001 & -0.525 \\
\hline
\end{tabular}

Pearson's correlation test

Table 3 shows a significant correlation between serum uric acid levels, urea, creatinine, and eGFR using the CKD-Epi method in type 2 DM patients with and without diabetic nephropathy. There was a significant positive correlation between serum uric acid, urea, and creatinine. A higher serum uric acid level led to more elevated urea and creatinine levels $(p<0.001)$. There was a significant negative correlation between serum uric acid levels and eGFR. A higher serum uric acid level led to the lower eGFR level $(p<0.001)$.

The mean value of uric acid in type 2 DM patients without nephropathy was $6.41 \pm 3.42$, and in type 2 DM patients with nephropathy was $9.57 \pm 3.42$. The mean value of uric acid was higher in type 2 DM patients with diabetic nephropathy than in type 2 DM patients without diabetic nephropathy. This finding was because of decreased glomerular filtration, increased proximal tubular reabsorption, and decreased distal tubular secretion in diabetic nephropathy. Increased serum uric acid levels can result from impaired kidney function, although serum uric acid also contributes to reduced kidney function. ${ }^{10,11}$

Uric acid has a positive correlation with urea and creatinine. The correlation between uric acid and urea was more significant than the correlation between uric acid and creatinine. In addition to being endogenous, serum urea and uric acid are affected by diet, while dietary protein does not influence creatinine levels. Serum creatinine is the result of a constant breakdown of creatinine phosphate in muscle. Serum creatinine levels depend on muscle mass. Urea is the end product of protein and amino acid catabolism produced by the liver and distributed through intracellular and extracellular fluids into the blood to be filtered by the glomerulus. Decreased renal function in diabetic nephropathy results in decreased excretion of urea and creatinine into the urine. ${ }^{12}$

The positive correlation between serum uric acid with urea and creatinine in this study was in line with studies by Chan et al., Yan et al., Chini et al. ${ }^{79,13}$ The increased creatinine in DM can be caused by several mechanisms, including uric acid transport to vascular smooth muscle, causing decreased production and release of Nitric Oxide (NO). Reduced NO causes endothelial dysfunction and induces oxidative stress, which causes pre-glomerular arteriolar damage. Pre-glomerular arteriolar damage causes glomerular hemodynamic changes and causes or stimulates the progression of diabetic renal impairment. Uric acid can induce proliferation of vascular smooth muscle cell by activating the intracellular MAPK pathway and nuclear transcription factors (NF-kB and AP- 1 ). ${ }^{9,10}$

There was a negative correlation between serum uric acid levels and eGFR. The estimated glomerular filtrate rate represents creatinine clearance filtered by the kidneys. These results were in line with research by Chowta, and Chini et al. ${ }^{13,14}$ Estimated glomerular filtrate rate use creatinine parameters to assess renal function. Decreased kidney function will lead to impaired clearance of uric acid. ${ }^{15-17}$

This research was a retrospective study; thus, several factors that may bias the study results were unable to be controlled. These factors include diet, smoking, stress, BMI, DM duration, glycemic control, and comorbidities. Measurement of uric acid, urea and creatinine levels, which was carried out on three 
different devices and the calculation of eGFR using a formula, which was not specific to the Indonesian population, were limitations of this study.

\section{CONCLUSIONS AND SUGGESTIONS}

This study concluded that the uric acid levels in diabetic nephropathy patients were higher than in patients without diabetic nephropathy. A more elevated urea and creatinine levels led to a higher serum uric acid level. Contrastingly, a lower eGFR showed a higher uric acid level. Increased serum uric acid levels can be the cause or result of diabetic nephropathy. Further research using the cohort method and considering dietary factors, lifestyle, comorbidities, DM duration, and glycemic control was needed.

\section{REFERENCES}

1. Oliveira EP, Burini RC. High plasma uric acid concentration: Cause and consequences. Diabetology Metabolic Syndrome Journal, 2012; 4(12): 1-7. Available from: https://www.ncbi.nlm.nih.gov (accessed 10 August, 2019).

2. Momeni A. Serum uric acid and diabetic nephropathy. Journal of renal injury Prevention. 2012; 1(1): 37-38. Available from: https://www.ncbi.nlm.nih.gov (accessed 2 August, 2019).

3. Hendromartono. Nefropati diabetik. Buku Ajar Ilmu Penyakit Dalam. Ed 4., jilid III. Jakarta, Departemen Ilmu Penyakit Dalam FK UI, 2006; 1942-1946.

4. Konsensus pengelolaan dan pencegahan diabetes melitus tipe 2 di Indonesia. PERKENI. 2015; 11.

5. Kementerian Kesehatan Republik Indonesia. Hasil utama RISKESDAS. 2018; 70.

6. Jalal DI, Maahs DM, Hovind P, Nakagawa T. Uric acid as a mediator of diabetic nephropathy. National Institute of Health Public Access. 2011; 32(5): 459-465. Available from: https://www.ncbi.nlm.nih.gov (accessed 12 July, 2019)

7. Chan, Gary C.W Diabetic nephropathy: Landmark clinical trials and tribulations. Oxford University Press, Nephrology Dialysis Transplantation, 2015; 31: 359-368. Available from: https://www.ncbi. nlm.nih.gov (accessed 4 August, 2019).

8. Sautin YY, Johnson RJ. Uric acid: The oxidant-antioxidant paradox. National Institute of Health Public Access, 2008; 27(6): 608-619. Available from: https://researchgate.net (accessed 12 July, 2019).

9. Yan D, Tu J, Jiang F, Wang J, Zang $R$, et al. Uric acid is independently associated with diabetic kidney disease: A cross-sectional study in a Chinese population. 2015; 10(6): 1-9. Available from: https://www.ncbi.nlm.nih.gov (accessed 12 July, 2019).

10. Kafeshani M. The relationship between chronic kidney disease, uric acid, and dietary factors; an updated review. Journal of Renal Endocrinology, 2017; 3: 1-5. Available from: http://www.jrenendo.com (accessed 10 August, 2019)

11. Gu L, Huang L, Wu H, Lou Q, Bian R. Serum uric acid to creatinine ratio: A predictor of incident chronic kidney disease in type 2 diabetes mellitus patients with preserved kidney function. Diabetes \& Vascular Disease Research, 2017; 14(3): 221-225.

12. Verdiansah. Pemeriksaan fungsi ginjal. Cermin Dunia Kedokteran, 2016; 148-54.

13. Chini LSN, Assis LIS, Lugon JR. Relationship between uric acid levels and risk of chronic kidney disease in retrospective cohort of Brazillian workers. Brazilian Journal of Medical and Biological Research. 2017; 50(9): 1-7. Available from: http://dx.doi.org/10.1590/ 1414-431X20176048 (accessed 12 August, 2019).

14. Chowta NK, Chowta MN. Association of uric acid level with estimated glomerular filtration rate in diabetic patients. Archives of Medicine and Health Sciences. 2014; 2(2): 145-49.

15. Usama AA, Din SE, Salem MM, Abdulazim DO. Uric acid in the pathogenesis of metabolic, renal, and cardiovascular disease: A review. Journal of Advanced Research 8. 2017; 537-548. Available from: http://dx.doi.org/10.1016/j.jare.2016.11.004. (accessed 1 July, 2019).

16. Bjornstad $P$, Lanaspa MA, Ishimoto $T$, Kosugi $T$, Kume $S$, et al. Fructose and uric acid in diabetic nephropathy. Diabetologia, 2015; 58(9): 1-21.

17. Li GX, Jiao XH, Cheng XB. Correlations between blood uric acid and the incidence and progression of type 2 diabetes nephropathy. European Pharmacological Sciences Review for Medical and Pharmacological Sciences. 2018; 22: 506-511. 